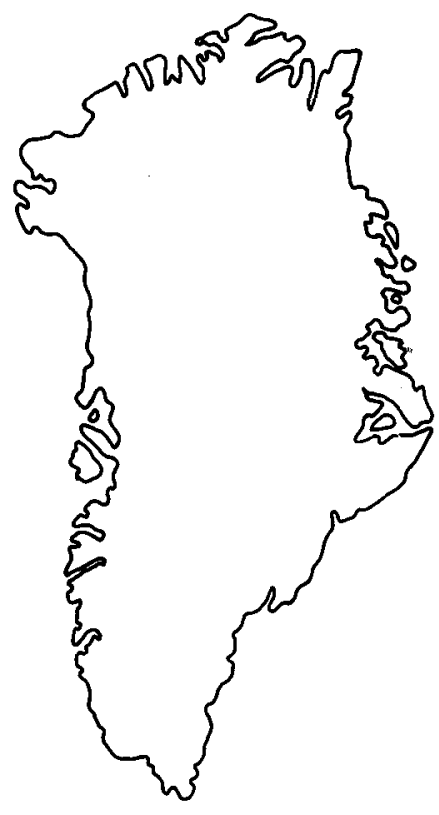

\title{
Gardar mantle xenoliths: Igdlutalik, South Greenland
}

\author{
Brian G. J. Upton
}

\begin{abstract}
A dyke of presumed Gardar age on Igdlutalik island near Narsaq contains an abundance of ultramafic xenoliths. Both host rock and xenoliths have been metamorphosed and the original mineral assemblages largely replaced by tremolite, chlorite and magnetite.

Textural and geochemical evidence suggests: (a) that the host rock was a part of the ultramafic lamprophyre suite known throughout the Tugtutôq-Ilímaussaq-nunataq lineament, and (b) that the xenoliths were mantle-derived peridotites (possibly garnetiferous), together with some glimmerites that may be analogues of MARIDsuite xenoliths known from kimberlite occurrences.
\end{abstract}

B. G. J. U., Department of Geology and Geophysics, University of Edinburgh, Edinburgh EH9 3JW, U.K.

The Gardar alkaline igneous province in South Greenland comprises a wide range of mildly to strongly alkaline rocks erupted in mid-Proterozoic times (approximately $1320-1120 \mathrm{Ma}$ ) across the southern part of the Greenland craton and the Proterozoic Ketilidian terrain to the south of it. Basic magmas in the province were predominantly mildly alkaline olivine-basalts and hawaiites. Relatively low $m g$ numbers and $\mathrm{Ni}$ and $\mathrm{Cr}$ contents signify their derivative nature, and extensive lower crustal or sub-crustal under-plating is presumed to have attended their fractional crystallisation histories (Upton \& Emeleus, 1987).

More primitive magma compositions are represented by suites of lamprophyric minor intrusions (mainly dykes) emplaced at several stages in different parts of the Gardar province. These include, for example, the ultramafic aillikites and alnöites found within the Tugtutôq-Ilímaussaq-nunataq lineament in the southern part of the province (Craven, 1985; Upton \& Emeleus, 1987).

The ultramafic lamprophyres commonly possess a nodular weathering pattern: the heterogeneity that gives these patterns may be partly due to xenocrystal fragments of mantle wall-rocks which almost invariably underwent secondary carbonation as a result of deuteric processes. Clear and unequivocal examples of primitive magmas erupted with sufficient velocity to entrain substantial xenoliths of mantle rocks are, however, exceedingly rare in the Gardar province. It is the purpose of this paper to describe a small intrusion on Igdlutalik island near Narsaq, which is crowded with such xeno- liths. A brief note on this locality has been presented by Scott-Smith (1987).

\section{Analytical techniques}

Mineral analyses were made on a Cambridge Scientific Instruments Microscan 5 electron-probe microanalyser at Edinburgh University using the wavelength dispersive method. The standards used were of pure elements, oxides or simple silicate compositions. Corrections were made for dead-time, atomic number, absorption and fluorescence, using computer programs based on the methods of Sweatman \& Long (1969).

The whole-rock analyses were made at Edinburgh University using Philips PW1450 and PW1480 automatic XRF spectrometers. Major elements were determined on fused glass discs (Norrish \& Hutton, 1969) with corrections applied for inter-element mass absorption effects. Trace elements were determined using pressed powder discs and corrected for mass absorption effects with coefficients calculated from the major element analyses. USGS and CRPG rock standards (Abbey, 1980) were used in the calibration of both major and trace elements. The precision and accuracy of the methods used have been described by Thirlwall (1979) and Fitton \& Dunlop (1985).

\section{The xenolithic intrusion}

The intrusion is a dyke-like body, outcropping at Karra on the WSW end of Igdlutalik (Fig. 1). The body 

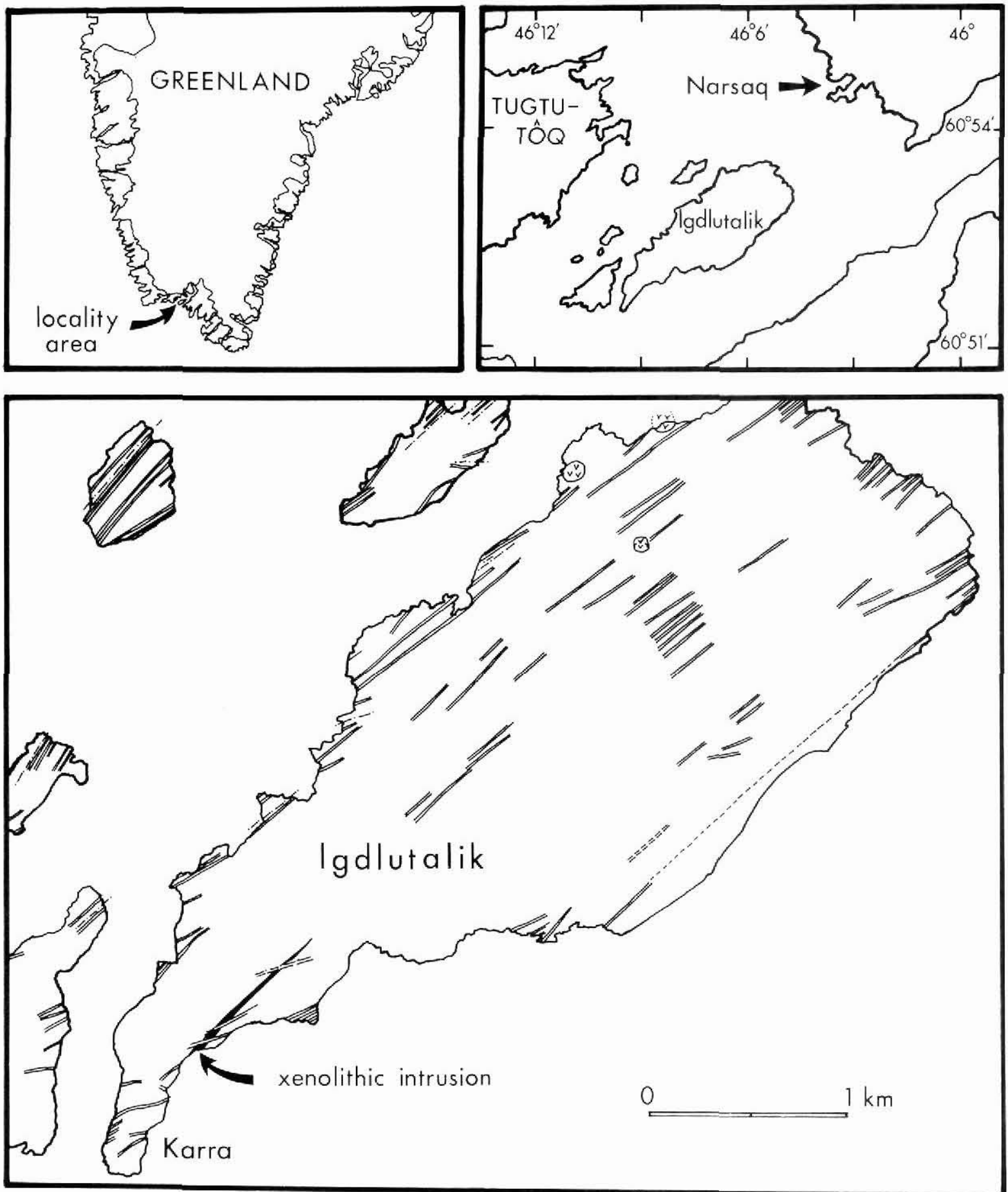

Fig. 1. Sketch map of Igdlutalik and its position.

trends ENE-WSW, parallel to the principal direction of shearing and dyke injection that characterises the Tugtutôq lineament. It can be traced for $c .0 .5 \mathrm{~km}$ and has a maximum width of $c .12 \mathrm{~m}$. It appears to have been emplaced along a crush zone within the early Proterozoic (Ketilidian) granodiorites and is itself partly sheared. It is cut by an irregular sheet (c. $50 \mathrm{~m}$ thick) of albititic rock and by one or two dykes of the late Gardar 


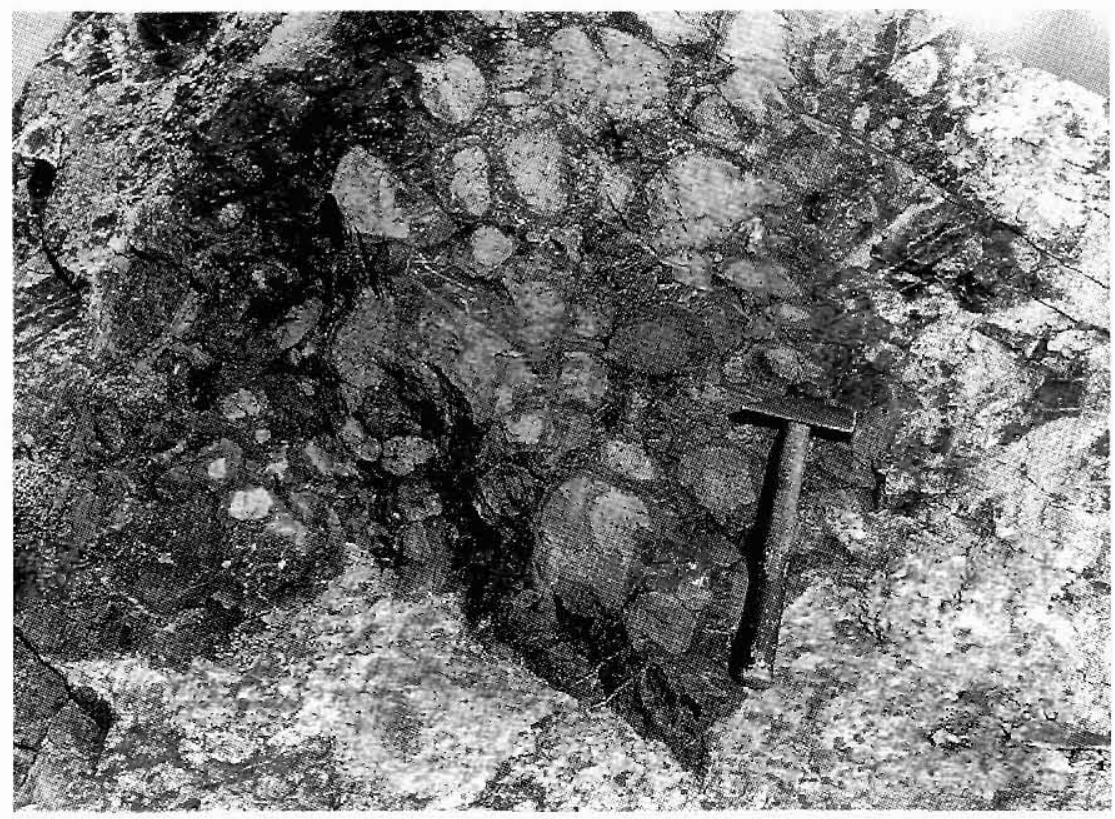

Fig. 2. Outcrop surface of intrusion showing ultramafic xenoliths. (Hammer shaft c. $29 \mathrm{~cm}$.)

dyke swarm. Its age is thus crudely bracketed between the Ketilidian granodiorites (c. $1750 \mathrm{Ma}$ ) and the late Gardar dykes (c. $1150 \mathrm{Ma}$ ), and a Gardar age is probable.

The intrusion is composed of a fine-grained, black host containing an abundance of rounded to sub-angular ultramafic xenoliths, up to $40 \mathrm{~cm}$ in diameter (Fig. 2). The xenoliths are packed so closely as to be mainly in contact with each other. The intrusion could thus be described as 'clast supported' and involving over $50 \%$ by volume of xenoliths.

The xenoliths fall into two principal categories. The first and most abundant are pale coloured and commonly show an outer concentric shell. They are composed predominantly of tremolitic amphibole, with lesser penninitic chlorite, magnetite, hematite and chrome-spinel. In one instance relic olivine $\left(\mathrm{Fo}_{91.6-91.3}\right)$ was found in a xenolith core. These pale xenoliths are inferred to have been peridotite blocks that have undergone pervasive recrystallisation to tremolite-chlorite assemblages. The original fabric of these rocks has been almost wholly obliterated during the metamorphism. However, concentrations of 'dusty' magnetite inclusions help to define what appear to be former crystal boundaries. The pseudomorphed crystals, typically $2-3 \mathrm{~mm}$ across, appear to have commonly possessed $120^{\circ}$ triple grain boundaries and the rocks may have formerly been coarse peridotites, using the terminology of Harte (1977). Some of the pseudomorphed crystals are distinct in being richer in microscopic opaque inclusions. It is tentatively concluded that these represent altered pyroxenes, whereas the majority of less clouded pseudomorphs are thought to be secondary after olivine.

Occasionally the pale xenoliths contain roughly equidimensional clots up to $3 \mathrm{~mm}$ in diameter, whose margins consist of intergrown tremolite and magnetite and whose centres contain deep red to orange-brown translucent chrome-spinel. Although these clots may represent partly recrystallised larger spinels it is suggested that they may be breakdown products from former chromiferous pyrope crystals. The abundant pale xenoliths then may be recrystallised blocks of garnet harzburgite or garnet lherzolite. The compositions of some representative tremolite, chlorite, spinel etc. from these pale xenoliths are presented in Table 1.

A second, subordinate, category of xenoliths consists of dark greenish-black glimmerite. The glimmerite xenoliths are composed of $>85 \%$ phlogopite. The phlogopite crystals are up to $2 \mathrm{~mm}$ across and typically show a random (decussate) texture. In thin-section they display pleochroism from virtually colourless to pale bluegreen. Small zircon crystals are present in the glimmerite crystals with brownish radiation halos produced in the micas around zircon inclusions. Interstitial calcite occurs up to $10 \%$ modally. The glimmerite crystals also contain accessory sphene (up to $1 \mathrm{~mm}$, as brownish, anhedral crystals) and small stubby prisms of apatite.

Compared to phlogopites from the mica-amphibolerutile-ilmenite-diopside xenoliths (MARID-suite) of kimberlites, reviewed by Dawson (1987), the micas in 
Table 1. Representative (microprobe) analyses of minerals from xenoliths and host-rock

\begin{tabular}{|c|c|c|c|c|c|c|c|c|c|c|c|c|c|c|}
\hline & 1 & 2 & 3 & 4 & 5 & 6 & 7 & 8 & 9 & 10 & 11 & 12 & 13 & 14 \\
\hline $\mathrm{SiO}_{2}$ & 57.64 & 53.71 & 56.39 & 56.76 & 33.76 & 41.19 & 43.32 & 0.08 & 0.39 & - & - & 37.91 & 38.69 & 40.74 \\
\hline $\mathrm{Al}_{2} \mathrm{O}_{3}$ & 3.03 & 2.97 & 0.84 & 0.85 & 12.69 & 7.99 & 0.20 & 0.03 & 0.04 & 14.73 & 30.02 & 16.47 & 14.40 & - \\
\hline $\mathrm{FeO}^{*}$ & 1.21 & 2.40 & 2.01 & 2.05 & 5.30 & 4.05 & 3.20 & 67.45 & 91.01 & 18.80 & 13.83 & 10.55 & 11.19 & 8.32 \\
\hline $\mathrm{MnO}$ & 0.05 & 0.08 & 0.07 & 0.09 & 0.09 & 0.09 & 0.06 & 2.46 & 0.05 & 0.94 & 0.47 & 0.12 & 0.10 & 0.14 \\
\hline $\mathrm{MgO}$ & 23.47 & 22.41 & 23.40 & 23.37 & 32.02 & 30.06 & 38.36 & 0.23 & 0.23 & 11.79 & 16.44 & 18.27 & 18.86 & 50.82 \\
\hline $\mathrm{CaO}$ & 13.42 & 13.02 & 12.90 & 13.21 & 0.02 & 0.37 & $=$ & - & - & - & - & - & - & 0.03 \\
\hline $\mathrm{Na}_{2} \mathrm{O}$ & 0.17 & 0.75 & 0.26 & 0.31 & 0.10 & 0.12 & 0.02 & - & 0.02 & - & - & 0.08 & 0.10 & - \\
\hline $\mathrm{K}_{2} \mathrm{O}$ & 0.04 & 0.10 & 0.04 & 0.03 & 0.54 & 0.18 & 0.02 & - & - & - & - & 10.39 & 10.27 & - \\
\hline $\mathrm{TiO}_{2}$ & 0.17 & 0.48 & 0.18 & 0.12 & - & - & 0.12 & 24.58 & 0.20 & 0.18 & - & 0.29 & 0.59 & - \\
\hline \multirow{3}{*}{$\mathrm{Cr}_{2} \mathrm{O}_{3}$} & - & 0.02 & - & - & - & - & - & 2.67 & 0.36 & 53.81 & 39.49 & - & - & - \\
\hline & 96.48 & 95.95 & 96.09 & 96.80 & 84.51 & 84.05 & 85.20 & 97.51 & 92.31 & 100.25 & 100.25 & 94.07 & 94.19 & 100.04 \\
\hline & \multicolumn{4}{|c|}{$\begin{array}{l}\text { cations } \\
(0=23)\end{array}$} & \multicolumn{3}{|c|}{$\begin{array}{l}\text { cations } \\
(0=36)\end{array}$} & $\begin{array}{l}\text { cations } \\
(0=32)\end{array}$ & $\begin{array}{l}\text { cations } \\
(0=3)\end{array}$ & \multicolumn{2}{|c|}{$\begin{array}{l}\text { cations } \\
(0=32)\end{array}$} & \multicolumn{2}{|c|}{$\begin{array}{l}\text { cations } \\
(0=22)\end{array}$} & $\begin{array}{l}\text { cations } \\
(0=4)\end{array}$ \\
\hline $\mathrm{Si}$ & 7.953 & 7.549 & 7.849 & 7.850 & 8.521 & 10.197 & 10.613 & 0.027 & 0.015 & - & - & 5.627 & 5.754 & 0.992 \\
\hline $\mathrm{Al}$ & 0.049 & 0.491 & 0.137 & 0.139 & 3.775 & 2.334 & 0.058 & 0.011 & 0.002 & 4.474 & 8.303 & 2.881 & 2.524 & - \\
\hline $\mathrm{Fe}$ & 0.140 & 0.282 & 0.234 & 0.237 & 1.118 & 0.839 & 0.655 & 18.191 & 2.924 & 4.048 & 2.714 & 1.309 & 1.392 & 0.169 \\
\hline Mn & 0.006 & 0.010 & 0.004 & 0.011 & 0.019 & 0.019 & 0.014 & 0.672 & 0.002 & 0.203 & 0.096 & 0.015 & 0.013 & 0.003 \\
\hline $\mathrm{Mg}$ & 4.827 & 4.695 & 4.855 & 4.817 & 12.043 & 11.093 & 14.004 & 0.112 & 0.013 & 4.528 & 5.749 & 4.041 & 4.189 & 1.844 \\
\hline $\mathrm{Ca}$ & 1.985 & 1.961 & 1.924 & 1.958 & 0.005 & 0.099 & - & - & 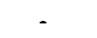 & - & - & - & - & 0.000 \\
\hline $\mathrm{Na}$ & 0.045 & 0.206 & 0.069 & 0.083 & 0.049 & 0.058 & 0.011 & - & 0.002 & - & - & 0.024 & 0.028 & - \\
\hline K & 0.007 & 0.017 & 0.007 & 0.006 & 0.172 & 0.056 & 0.007 & - & - & - & - & 1.967 & 1.948 & - \\
\hline $\mathrm{Ti}$ & 0.018 & 0.051 & 0.019 & 0.012 & - & - & - & 5.962 & 0.006 & 0.037 & - & 0.032 & 0.066 & - \\
\hline \multirow[t]{2}{*}{$\mathrm{Cr}$} & - & 0.002 & - & - & - & - & - & 0.683 & 0.011 & 10.959 & 7.322 & - & - & - \\
\hline & 15.030 & 15.264 & 15.102 & 15.113 & 25.702 & 24.695 & 25.362 & 25.658 & 2.974 & 24.249 & 24.184 & 15.896 & 15.906 & 3.008 \\
\hline $\begin{array}{l}\frac{\mathrm{Mg} \cdot 100}{(\mathrm{Mg}+\mathrm{Fe}+\mathrm{M} n)} \\
\mathrm{Al} / \mathrm{Cr}\end{array}$ & 97.06 & 94.14 & 99.84 & 99.77 & 91.37 & 92.82 & 95.44 & & & 0.41 & 1.13 & 75.32 & 74.84 & 91.46 \\
\hline
\end{tabular}

$\mathrm{FeO}^{*}=$ total $\mathrm{FeO}+\mathrm{Fe}_{2} \mathrm{O}_{3}$ expressed as $\mathrm{FeO}$.
1. GGU 181918, tremolite, host rock.
2. GGU 181916A, tremolite; host rock.
3. GGU 181916A, tremolite, pale xenolith.
4. GGU 65121, tremolite, pale xenolith.
5. GGU 181918, chlorite, host rock.
6. GGU 181918, chlorite, pale xenolith.
7. GGU 65121, chlorite, pale xenolith.

the Igdlutalik glimmerites are distinctly poor in $\mathrm{SiO}_{2}$ and $\mathrm{MgO}$ but richer in $\mathrm{Al}_{2} \mathrm{O}_{3}$ and total $\mathrm{FeO}+\mathrm{Fe}_{2} \mathrm{O}_{3}$ (Table 1). MARID-suite micas are reported to have $m g$ numbers (atomic $\mathrm{Mg} /(\mathrm{Mg}+\mathrm{Fe})$ ) ranging from 0.81 to 0.92 . In contrast those of the Igdlutalik glimmerites have $m g$ numbers of $c$. 0.75 . The high contents of $\mathrm{Rb}$ and $\mathrm{Ba}$ for the glimmerite whole-rock analyses (Table 2) undoubtedly reflect high contents in the micas.

\section{Whole-rock compositions of the xenoliths}

Five XRF analyses of material from the pale xenoliths are given in Table 2. The lower silica and higher iron contents in analyses 1 and 4 are mainly attributable to the higher contents of oxide minerals. As stated above,
8. GGU 181916A, magnetite, pale xenolith.

9. GGU 181918, hematite, host rock.

10. GGU 181916, Cr-spinel, host rock.

11. GGU 65121, Cr-spinel, pale xenolith.

12. GGU 181915, phlogopite, glimmerite xenolith.

13. GGU 181915, phlogopite, glimmerite xenolith.

14. GGU 65121, olivine, core of pale xenolith. many of the xenoliths show a metamorphic differentiation into an outer shell and an inner core. Analyses 1 and 2 are from the shell and core, respectively, of one such concentrically shelled xenolith.

Mean compositions for spinel lherzolite and garnet lherzolite xenoliths have been presented by Maaløe \& Aoki (1977) and Carswell (1980) (Table 3). If it is assumed that the Igdlutalik pale xenoliths are derived from comparable mantle peridotites, a considerable degree of major-element exchange during metamorphism is implied.

$\mathrm{MgO}$ is typically in the range $39-44 \mathrm{wt} \%$ for mantle peridotites. $\mathrm{MgO}$ may have been reduced by metasomatic leaching by a factor of about $>2$ in the Igdlutalik samples. $\mathrm{Al}_{2} \mathrm{O}_{3}$ values also tend to be low and alumina 
Table 2. Whole-rock analyses of xenoliths

\begin{tabular}{|c|c|c|c|c|c|c|c|c|}
\hline & 1 & 2 & 3 & 4 & 5 & 6 & 7 & 8 \\
\hline $\mathrm{SiO}_{2}$ & 52.46 & 42.19 & 50.23 & 49.63 & 45.05 & 37.89 & 38.42 & 36.92 \\
\hline $\mathrm{Al}_{2} \mathrm{O}_{3}$ & 0.62 & 0.94 & 1.36 & 2.20 & 2.14 & 13.72 & 11.43 & 13.14 \\
\hline $\mathrm{Fe}_{2} \mathrm{O}_{3}^{*}$ & 7.04 & 16.86 & 9.39 & 9.48 & 17.39 & 14.01 & 14.78 & 12.78 \\
\hline $\mathrm{MnO}$ & 0.08 & 0.10 & 0.08 & 0.10 & 0.07 & 0.10 & 0.13 & 0.12 \\
\hline $\mathrm{MgO}$ & 21.90 & 27.14 & 21.16 & 22.04 & 21.14 & 17.84 & 15.30 & 17.82 \\
\hline $\mathrm{CaO}$ & 14.47 & 3.52 & 12.89 & 10.83 & 9.19 & 1.41 & 6.49 & 3.25 \\
\hline $\mathrm{Na}_{2} \mathrm{O}$ & - & - & - & - & - & - & 0.22 & - \\
\hline $\mathrm{K}_{2} \mathrm{O}$ & 0.09 & 0.16 & 0.32 & 0.05 & 0.04 & 9.11 & 6.36 & 8.75 \\
\hline $\mathrm{TiO}_{2}$ & 0.05 & 0.05 & 0.32 & 0.59 & 0.27 & 0.66 & 0.89 & 0.57 \\
\hline $\mathrm{P}_{2} \mathrm{O}_{5}$ & 0.03 & 0.04 & 0.08 & 0.10 & 0.04 & 0.29 & 0.44 & 0.27 \\
\hline \multirow[t]{2}{*}{ 1.o.i. } & 2.77 & 8.05 & 2.88 & 3.26 & 3.50 & 3.10 & 4.15 & 4.69 \\
\hline & 98.64 & 98.96 & 98.67 & 98.23 & 98.77 & 98.06 & 98.61 & 98.20 \\
\hline \multicolumn{9}{|c|}{ Trace elements (ppm) } \\
\hline $\mathrm{Ni}$ & 1604 & 2426 & 1547 & 868 & 1870 & 841 & 787 & 756 \\
\hline $\mathrm{Cr}$ & 2515 & 2801 & 3808 & 6310 & 2125 & 73 & 121 & 81 \\
\hline $\mathrm{V}$ & 51 & 78 & 76 & 129 & 147 & 115 & 205 & 134 \\
\hline $\mathrm{Sc}$ & 11 & 7 & 15 & 23 & 13 & 3 & 19 & 9 \\
\hline $\mathrm{Cu}$ & 41 & 516 & 58 & 9 & 23 & 0 & - & - \\
\hline $\mathrm{Zn}$ & 64 & 88 & 89 & 238 & 207 & 185 & 152 & 266 \\
\hline $\mathrm{Sr}$ & 96 & 25 & 79 & 125 & 63 & 143 & 297 & 218 \\
\hline $\mathbf{R b}$ & 14 & 25 & 58 & 4 & 3 & 1486 & 923 & 1373 \\
\hline $\mathrm{Zr}$ & 12 & 10 & 34 & 46 & 18 & 259 & 336 & 279 \\
\hline $\mathrm{Nb}$ & 4 & 3 & 9 & 15 & 19 & 15 & 18 & 11 \\
\hline $\mathrm{Ba}$ & 15 & 12 & 17 & 27 & 9 & 262 & 290 & 147 \\
\hline $\mathrm{Pb}$ & 21 & 1 & 20 & 2 & 5 & - & 8 & 11 \\
\hline Th & - & - & - & - & - & 22 & 23 & 32 \\
\hline La & 0 & 5 & 1 & 4 & 7 & 123 & 682 & 478 \\
\hline $\mathrm{Ce}$ & - & - & - & - & 9 & 210 & 1180 & 777 \\
\hline $\mathrm{Nd}$ & - & - & - & - & 6 & 61 & 415 & 193 \\
\hline$Y$ & 4 & 4 & 6 & 8 & 7 & 30 & 33 & 31 \\
\hline
\end{tabular}

$\mathrm{Fe}_{2} \mathrm{O}_{3}{ }^{*}=$ total $\mathrm{Fe}$ expressed as $\mathrm{Fe}_{2} \mathrm{O}_{3}$.

1. GGU 65121-1, pale xenolith (outer shell).

2. GGU 65121-1, pale xenolith (core).

3. GGU 65121-3, pale xenolith.

4. GGU 65121-4, pale xenolith.

loss is suspected. The principal gains would therefore appear to be in $\mathrm{CaO}, \mathrm{Fe}_{2} \mathrm{O}_{3}{ }^{*}$ and $\mathrm{SiO}_{2}$.

With respect to the trace elements, the $\mathrm{Ni}$ and $\mathrm{Cr}$ contents (in the ranges $860-2430$ and $2120-6310$, respectively) are of the right order of magnitude for mantle peridotites (cf. Basaltic Volcanism Study Project, 1981, pp. 291 \& 298).

Three glimmerite xenoliths were also analysed (Table 2 , analyses 6, 7 and 8 ). These, too, contain relatively high $\mathrm{Ni}(800 \pm 50 \mathrm{ppm})$. The high $\mathrm{P}$ and $\mathrm{Zr}$ contents (relative to the pale xenoliths) correspond to the presence of apatite and zircon. The high LREE and $Y$ contents are inferred to be distributed mainly between the apatite and the sphene while the high Th is likely to
5. GGU 65121-9, pale xenolith

6. GGU 50170, glimmerite xenolith.

7. GGU 181913E, glimmerite xenolith.

8. GGU 181915, glimmerite xenolith.

be hosted by the zircons and to be responsible for their associated (radiation-damage) halos.

\section{The host rock}

The host rock, like the majority of the xenoliths, is largely composed of tremolite and chlorite. However, the darker colour is conferred by its much higher proportion of opaque oxides (magnetite and some hematite). Like the xenoliths the host appears to have been thoroughly recrystallised and it is difficult to make categorical assertions with regard to its pre-metamorphic texture. Nonetheless it is inferred that much of the tremolite is secondary after olivine and the host could 
Table 3. Mean compositions of mantle lherzolite xenoliths

\begin{tabular}{lrr}
\hline & \multicolumn{1}{c}{1} & \multicolumn{1}{c}{2} \\
\hline $\mathrm{SiO}_{2}$ & 44.20 & 45.83 \\
$\mathrm{Al}_{2} \mathrm{O}_{3}$ & 2.05 & 1.57 \\
$\mathrm{Fe}_{2} \mathrm{O}_{3}{ }^{*}$ & 9.20 & 7.66 \\
$\mathrm{MnO}$ & 0.13 & 0.29 \\
$\mathrm{MgO}$ & 42.21 & 43.41 \\
$\mathrm{CaO}$ & 1.92 & 1.16 \\
$\mathrm{Na}$ & 0.27 & 0.16 \\
$\mathrm{~K}_{2} \mathrm{O}$ & 0.06 & 0.12 \\
$\mathrm{TiO}_{2}$ & 0.13 & 0.09 \\
$\mathrm{P}_{2} \mathrm{O}_{5}$ & 0.03 & 0.04 \\
$\mathrm{NiO}_{\mathrm{Cr}}$ & 0.28 & 0.29 \\
$\mathrm{H}_{2} \mathrm{O}_{3}$ & 0.44 & 0.32 \\
$\mathrm{CO}_{2}$ & n.d. & n.d. \\
& n.d. & n.d. \\
& 100.92 & 100.94 \\
\hline
\end{tabular}

$\mathrm{Fe}_{2} \mathrm{O}_{3}{ }^{*}=$ total $\mathrm{Fe}$ expressed as $\mathrm{Fe}_{2} \mathrm{O}_{3}$.

n.d. $=$ not determined.

1. Mean compositions of 384 spinel lherzolite xenoliths (after Maaløe \& Aoki, 1977).

2. Mean compositions of 61 garnet lherzolite xenoliths (after Carswell, 1980).

well have been highly olivine-phyric, with phenocrysts up to $2 \mathrm{~mm}$ across. Elongate pseudomorphs, rich in magnetite, appear to be secondary after a primary prismatic mineral. It is, however, indeterminate whether this may have been pyroxene, melilite or even a mica. Much of the interstitial material between the inferred olivine pseudomorphs and the magnetite-rich pseudomorphs may have been glass. Small apatite prisms are the only component that may have been unaffected by the metamorphism.

Although analytical data from such comprehensively altered rocks requires to be treated with great caution, some guidance as to the nature of the original magmatic composition can be gleaned. Two samples of host rock, separated as cleanly as possible from xenolithic matter, were analysed (Table 4).

The analyses suggest that the host magma was a silicapoor ultramafite. Low silica and alumina contents confirm petrographic indications that the host rock was feldspar free. The very high $\mathrm{Ni}$ and $\mathrm{Cr}$ contents confirm the highly primitive nature of the host magma, and such composition as olivine melilitite, kimberlite or ultramafic lamprophyre could be appropriate.

Relatively high values for $\mathrm{P}_{2} \mathrm{O}_{5}, \mathrm{Zr}$ and $\mathrm{Nb}$ may denote original high incompatible element contents such
Table 4. Analyses of host rock to ultramafic xenoliths

\begin{tabular}{|c|c|c|}
\hline & 1 & 2 \\
\hline $\mathrm{SiO}_{2}$ & 35.60 & 35.65 \\
\hline $\mathrm{Al}_{2} \mathrm{O}_{3}$ & 6.04 & 6.95 \\
\hline $\mathrm{Fe}_{2} \mathrm{O}_{3}{ }^{*}$ & 17.04 & 12.25 \\
\hline $\mathrm{MnO}$ & 0.29 & 0.41 \\
\hline $\mathrm{MgO}$ & 24.13 & 27.99 \\
\hline $\mathrm{CaO}$ & 5.98 & 4.45 \\
\hline $\mathrm{Na}_{2} \mathrm{O}$ & 0.18 & 0.03 \\
\hline $\mathrm{K}_{2} \mathrm{O}$ & 0.03 & 0.10 \\
\hline $\mathrm{TiO}_{2}$ & 3.52 & 4.06 \\
\hline $\mathrm{P}_{2} \mathrm{O}_{5}$ & 0.52 & 0.67 \\
\hline \multirow[t]{2}{*}{ 1.o.i. } & 6.41 & 7.84 \\
\hline & 99.75 & 100.40 \\
\hline \multicolumn{3}{|c|}{ Trace elements (ppm) } \\
\hline $\mathrm{Ni}$ & 825 & 893 \\
\hline $\mathrm{Cr}$ & 870 & 945 \\
\hline V & 246 & 315 \\
\hline Sc & 24 & 23 \\
\hline $\mathrm{Cu}$ & 8 & \\
\hline $\mathrm{Zn}$ & 109 & 91 \\
\hline $\mathrm{Sr}$ & 262 & 140 \\
\hline $\mathbf{R b}$ & 4 & 14 \\
\hline $\mathrm{Zr}$ & 259 & 293 \\
\hline $\mathrm{Nb}$ & 66 & 78 \\
\hline $\mathrm{Ba}$ & 24 & 33 \\
\hline $\mathrm{Pb}$ & 6 & 6 \\
\hline Th & 4 & 3 \\
\hline $\mathbf{L a}$ & 16 & 11 \\
\hline $\mathrm{Ce}$ & 47 & 26 \\
\hline $\mathrm{Nd}$ & 30 & 19 \\
\hline $\mathrm{Y}$ & 23 & 20 \\
\hline
\end{tabular}

$\mathrm{Fe}_{2} \mathrm{O}_{3}{ }^{*}=$ total $\mathrm{FeO}+\mathrm{Fe}_{2} \mathrm{O}_{3}$ expressed as $\mathrm{Fe}_{2} \mathrm{O}_{3}$.

1. Sample GGU 181916.

2. Sample GGU 181917.

as would be appropriate for very small degree partial melt fractions. The $\mathrm{Zr} / \mathrm{Nb}$ ratios $(3.92,3.76)$ are relatively constant and compare with values of $<4$ found for the ultramafic lamprophyres in the vicinity (Upton \& Emeleus, 1987).

Chondrite-normalised incompatible element patterns for the host rock are similar to those of ultramafic lamprophyres of Tugtutôq, Narsaq and the nunataq region to the ENE (Upton \& Emeleus, 1987, fig. 12). It is concluded that the Igdlutalik intrusion was a component of this suite of ultramafic lamprophyres that appears to have involved both melilite-bearing varietites (alnöites) and melilite-free, carbonate-rich varieties (aillikites) (Upton \& Emeleus, 1987). 
According to Rock (1986) many ultramafic lamprophyres represent primary magmas generated at depths between those of melilitites and kimberlites $(c$. 100-150 km) but at higher $P_{\mathrm{CO}_{2}}$ than melilitites.

\section{Discussion and summary}

On the basis of the composition of basic magmas erupted along the Tugtutôq-Ilímaussaq-nunataq lineament, it has been proposed earlier that these magmas originated within the lithospheric mantle (rather than in convecting asthenospheric mantle) and that the source rocks supplying the lineament had experienced a metasomatic enrichment involving addition of $\mathrm{K}, \mathrm{Ba}, \mathrm{Nb}, \mathrm{P}$ and LREE (Upton \& Emeleus, 1987). In the Igdlutalik xenoliths it is probable that we have a small, albeit altered, sample of the Gardar lithospheric mantle. If the majority of blocks were formerly garnet peridotites, the depth of origin may be presumed to be $>60 \mathrm{~km}$ and possibly $>100 \mathrm{~km}$. On the basis of the slender evidence presented here it is suggested that the xenoliths came from a region of peridotite permeated by veins of glimmerite. Such veins may well correspond to the veins of MARID-suite rocks believed to originate in upper mantle pegmatitic bodies by precipitation of phases from a hydrous melt enriched in REE, K, Rb, Sr, Ba, $\mathrm{Nb}$ and $\mathrm{Zr}$ (Dawson, 1987).

Metamorphism of the intrusion and its xenoliths is attributed to intense hydrothermal activity associated with emplacement of the younger dykes in the Tugtutôq swarm.

It is tentatively concluded that the intrusion in SW Igdlutalik represents a highly altered (metasomatised) lamprophyre that is part of the ultramafic lamprophyre suite occurring widely in the Tugtutôq-Ilímaussaq-nunataq lineament. The majority of the xenoliths were mantle-derived (garnet?) peridotites. Subordinate micaceous xenoliths may be related to the MARID-suite xenoliths reported from South African (and other) kimberlites.

Acknowledgements. The original field work was carried out under the auspices of the Geological Survey of Greenland. I am grateful to $P$. Hill and S. Cairns for help with microprobe analysis and to D. James and J. G. Fitton for the XRF data. Constructive criticism and helpful comment by J. G. Fitton, J. B. Dawson, L. M. Larsen and F. Kalsbeek is gratefully ac- knowledged. My thanks go also to D. Baty and Y. Cooper for assistance with draughting and photography, and to L. Begg for preparation of the manuscript.

\section{References}

Abbey, S. 1980: Studies in 'standard samples' for use in the general analysis of silicate rocks and minerals. Part 61979 edition of 'usable' values. Pap. geol. Surv. Can. 80-14, 30 pp.

Basaltic Volcanism Study Project 1981: Basaltic volcanism on the terrestrial planets, $1286 \mathrm{pp}$. New York: Pergamon Press, Inc.

Carswell, D. A. 1980: Mantle derived lherzolite nodules associated with kimberlite, carbonatite and basaltic magmatism: A review. Lithos 13, 121-138.

Craven, R. J. 1985: The petrogenesis of some ultramafic rocks from the Gardar province, S.W. Greenland. Unpublished Ph.D. thesis. Univ. of Edinburgh.

Dawson, J. B. 1987: The MARID suite of xenoliths in kimberlite: relationship to veined and metasomatised peridotite xenoliths. In Nixon, P. H. (ed.) Mantle xenoliths, 465-473. John Wiley \& Sons Ltd.

Fitton, J. G. \& Dunlop, H. M. 1985: The Cameroon line, West Africa, and its bearing on the origin of oceanic and continental alkali basalt. Earth Planet. Sci. Lett. 72, 23-38.

Harte, B. 1977: Rock nomenclature with particular relation to deformation and recrystallisation textures in olivine-bearing xenoliths. J. Geol. 85, 279-288.

Maaløe, S. \& Aoki, K. 1977: The major element composition of the upper mantle estimated from the composition of lherzolites. Contr. Mineral. Petrol. 63, 161-173.

Norrish, K. \& Hutton, J. T. 1969: An accurate X-ray spectrographic method for the analysis of a wide range of geological samples. Geochim. cosmochim. Acta 33, 431-453.

Rock, N. M. S. 1986: The nature and origin of ultramafic lamprophyres: Alnöites and related rocks. J. Petrol. 27, 155-196.

Scott-Smith, B. H. 1987: Greenland. In Nixon, P. H. (ed.) Mantle xenoliths, 23-32. John Wiley \& Sons Ltd.

Sweatman, T. R. \& Long, J. V. P. 1969: Quantitative electron probe microanalysis of rock-forming minerals. J. Petrol. 10, 332-379.

Thirlwall, M. F. 1979: The petrochemistry of the British Old Red Sandstone Province. Unpublished Ph.D. thesis. Univ. of Edinburgh.

Upton, B. G. J. \& Emeleus, C. H. 1987: Mid-Proterozoic alkaline magmatism in southern Greenland: The Gardar Province. In Fitton, J. G. \& Upton, B. G. J. (ed.) Alkaline igneous rocks. Spec. Publ. geol. Soc. Lond. 30, 449-471. 